\title{
COMPARISON OF CHEMICAL PROPERTIES AND APPLICATION AS ACID SOIL AMENDMENT OF PRETREATMENT CENTER SLAG AND OTHER SLAGS
}

\author{
Suwarno ${ }^{1}$, Itsuo Goto ${ }^{2}$, and Hiroshi Masujima ${ }^{2}$ \\ ${ }^{1}$ Department of Soil Sciences, Faculty of Agriculture, \\ Bogor Agricultural University \\ ${ }^{2}$ Laboratory of Soil Science, Department of Agricultural Chemistry, \\ Faculty of Agriculture, Tokyo University of Agriculture
}

\begin{abstract}
Chemical properties of Pretreatment center slag (PTC-slag) were analyzed and compared to those of converter slag (C slag) and blast furnace slag (BF slag). PTC slag had a high EC value as well as citric acid soluble $\mathrm{P}$ and contained more $\mathrm{Ca}, \mathrm{Si}, \mathrm{P}, \mathrm{K}$, and $\mathrm{Na}$ but less $\mathrm{Mg}$ and $\mathrm{Fe}$ than $\mathrm{C}$ slag. Compared to BF slag, PTC slag contained more $\mathrm{Fe}, \mathrm{Ca}, \mathrm{Mg}, \mathrm{P}, \mathrm{Mn}$, and $\mathrm{Na}$ but less $\mathrm{Si}, \mathrm{Al}$, and $\mathrm{K}$. Although neutralizing value of PTC slag was lower than that of $C$ slag, its ability to neutralize soil acidity was markedly higher

A pot experiment using Andisol from Tochigi Prefecture and komatsuna plant was carried out to evaluate PTC slag as liming material as well as P fertilizer. PTC slag, C slag, and dolomite were applied as liming materials and combined with super phosphate (SP). Addition of SP of 2.5 and $5.0 \%$ phosphate absorption coefficient (PAC) to PTC slag significantly improved the yield of komatsuna. This result, however, only apply for PTC slag adjusting soil pH to 6.5. Addition of the same dosage of SP to PTC slag adjusting soil pH to 7.5 did not give significant effect. On the other hand, addition of SP of 2.5 and $5.0 \%$ PAC to C slag or dolomite significantly improved the yield for both $\mathrm{C}$ slag or dolomite adjusting the soil $\mathrm{pH}$ to 6.5 and 7.5 .

Results of the experiment also indicated that PTC slag and C slag significantly increased soil $\mathrm{pH}$; exchangeable $\mathrm{Ca}$, and $\mathrm{Mg}$ and improved available $\mathrm{P}, \mathrm{B}$, and $\mathrm{Mn}$ in Andisol. The magnitudes of these effects of the two slags, however, were difference. As compared to $\mathrm{C}$ slag and dolomite, PTC slag increased lower exchangeable $\mathrm{Mg}$ but higher available $\mathrm{P}$. These results suggest that for acid soil amendment, PTC slag was better than dolomite and C slag due to the fact that this material supply more $P$ and $B$. Application of PTC slag as acid soil amendment will reduce the demand of $P$ fertilizer, and even in high dosage can meet the $P$ demand of komatsuna plant.
\end{abstract}

Key Words: acid soil amendment, converter slag, pretreatment center slag, phosphorus fertilizer

\section{INTRODUCTION}

Steel slag is a by-product formed in the process of steel manufacturing (Anon., 1996). In general, the process of steel manufacturing is divided into three processes namely iron-making, steel-making, and rolling processes (Umegaki, 1986). Based on these processes, steel slag can roughly be grouped into blast fumace aPnd steel-making slags Washimi, 1986). Blast furnace slag which is a by-product in the iron-making process can then be called ironmaking slag, whereas steel-making slag is a by product in the steel-making process. The refining of pig iron in the steel-making process is conducted by three methods: open-hearth fumace, converter (basic oxygen furnace) or electric furnace (Nishiwaki, 1986). Based on these methods of refining, steel-making slag is then classified into open-hearth, converter, and electric fumace slags.

In some steel plants, before the molten pig iron is conveyed to the converter, phosphorus, sulfur, and silicon contents are removed from the pig iron at the hot metal pretreatment center (Anon., 1994). Steel slag produced in this process is called pretreatment center slag (PTC slag). Compared to blast furnace slag, converter slag, or electric furnace slag. PTC slag contains more phosphorus.

Suwarno, I. Goto, H. Masujima. 1999. Comparison Of Chemical Properties and Application As Acid Soil Amendment of Pretreatment Center Slag and Other Slags. J. II. Tan. Lingk. 2(2): 8-17 
It has long been known that steel slag can be useful for agriculture. This material can be used as liming material for improving the condition of acid soils (Carter et al., 1951; Crane, 1930; Naftel, 1937). Goto (1987) found that converter slag was good material for liming material, whereas blast fumace slag was not suitable. Furthermore, in Andisol, effect of converter slag for liming material was better than that of dolomite (Suwarno and Goto, 1997) Moreover, steel slag containing high phosphorus element such as basic slag can also be used as phosphorus fertilizer (Tisdale ot al., 1985; Wild, 1988). As stated above, PTC slag is one of steel slag containing high phosphorus element. Therefore, it is potentially considerable to utilize this slag as liming material and phosphorus fertilizer.

Based on the explanation above, a series of experiment were carried out with the objectives: 1) to determine the chemical properties of PTC slag and 2) to evaluate PTC slag as liming material in addition to as phosphorus fertilizer.

\section{MATERIALS AND METHODS}

\section{Chemical Properties}

Chemical properties of PTC slag from Kawasaki Steel Mizushima Works were analyzed and compared to that of converter slag (C slag) and blast fumace slag (BF slag) from the same steel plant. The chemical properties determined in this study were $\mathrm{pH}$, electrical conductivity $(\mathrm{EC})$ and citric acid soluble $\mathrm{P}, \mathrm{B}$, and $\mathrm{Si}$, as well as the chemical composition. These analyses were determined by the same methods as that described previously (Suwamo and Goto, 1997).

\section{Ability to Neutralize Soil Acidity}

Various particle sizes of PTC slag and C slag were selected and their abilities to neutralize acidity of an Andisol and a Red-Yellow Podzolic (Ultisol) were measured by buffer curve method and compared to that of C slag in order to evaluate the ability of PTC slag in neutralizing soil acidity. The PTC and C slags $<2.0 \mathrm{~mm}$ were sieved to get a series of particle size: $<0.25,0.25-0.50,0.50-1.00$, and $1.00-2.00 \mathrm{~mm}$ which were named as: PTC 1, .PTC 2. PTC 3 and PTC 4 or $C 1, C 2, C 3$, and C4, respectively. A series of $10 \mathrm{~g}$ of air dried soil were placed in $100-\mathrm{ml}$ polyethylene bottles, to which 0 , $100,200,300,400,600$, or $800 \mathrm{mg}$ of each particle size of PTC slag or C sleg was added. The bottles with PTC or C-slag were watered with $25 \mathrm{ml}$ of deionized water, allowed for $24 \mathrm{~h}$ and then shaken for $5 \mathrm{~h}$. After shaking, $2.01 \mathrm{~min}^{-1}$ of air was flowed to the mixture for $2 \mathrm{~min}$, then the $\mathrm{pH}$ was measured using pH-meter and the results were plotted in the graph.

\section{Pot Experiment}

A pot experiment was carried out in the greenhouse of Tokyo University of Agriculture to evaluate the effects of PTC slag on plant growth and chemical properties of soil and to compare those effects to those of $\mathrm{C}$ slag and the common liming material (dolomite). The $A_{1}$ layer of Andisol from Kanuma, Tochigi Prefecture was used, and each pot (Neubeur's pot) was filled with $220 \mathrm{~g}$ of soil of an oven dried basis. PTC slag, C slag, and dolomite were applied in two dosage to adjust soil pH $\left(\mathrm{H}_{2} \mathrm{O}\right)$ to 6.5 and 7.5, which were determined by buffer curve method. The applied dosages for PTC slag were 10.5 and $24.8 \mathrm{~g} \mathrm{pot}^{-1}$, for $C$ slag were 12.3 and $35.2 \mathrm{~g} \mathrm{pot}^{-1}$, and for dolomite were 8.8 and $22.8 \mathrm{~g}$ pot $^{-1}$. These liming materials were combined with super phosphate (SP) that applied at a phosphate absorption coefficient (PAC) of $2.5 \%$ and $5 \%(0.94$ and $\left.1.88 \mathrm{~g} \mathrm{pot}^{-1}\right)$. The treatments were replicated three times and arranged in the completely randomized design (Steel and Torrie, 1980). In addition, each pot received $0.1 \mathrm{~g} \mathrm{~N} \mathrm{pot}^{-1}$ and $0.1 \mathrm{~g}$ $\mathrm{K}_{2} \mathrm{O}$ pot $^{-1}$ as basal fertilizer. On April 14, 1997, 15 seeds of Komatsuna (Brassica chinensis L. CV. Ryouryoku) were planted in each pot and then thinned to 5 plants at 10 days after sowing. These plants were harvested at 29 days after sowing, and the fresh weight of top part was measured.

\section{Plant Analysis}

Nutrient content of top part of komatsuna was analyzed to evaluate the effect of treatments on the nutrient absorption. After harvesting, those plant parts were rinsed with deionized water, dried at $60^{\circ}$ $C$, and then powdered. Sample was then digested by closed PTFE vessel acid digestion method and nutrient content was measured by ICP-AES

\section{Soil Analysis}

After harvesting, soil samples were taken from each pot. Chemical properties of soil sample analyzed were as follows: 1) $\mathrm{pH}$ : determined potentiometrically in water $(1: 5) ; 2$ ) exchangeable bases: extracted with $1 M$ ammonium acetate $\mathrm{pH}$ 7.0 and determined by ICP-AES; 3) available phosphorus: extracted with Olsen method and determined by spectrophotometer; 4) available $\mathrm{Mn}$ : extracted with DTPA method and determined by ICP-AES; 5) available B: extracted with $0.01 \mathrm{M}$ $\mathrm{CaCl}_{2}$ and determined by ICP-AES. 


\section{RESULTS AND DISCUSSION}

\section{Chemical Properties and Ability to Neutralize Soil Acidity}

Chemical characteristics of PTC-slag, C-slag, and BF-slag are presented in Table 1 and Table 2. As shown Table 1, PTC slag had high $\mathrm{pH}$ value that was not different from $\mathrm{C}$ slag. Furthermore, compared to C-slag and BF-slag, PTC-slag had higher EC value and citric acid soluble $P$ and $B$. However, for citric acid soluble Si, PTC-slag was higher than C-slag but lower than BF-slag.

As shown in Table 2, PTC-slag contained more Ca, $\mathrm{Si}, \mathrm{P}, \mathrm{K}$, and $\mathrm{Na}$ but less $\mathrm{Mg}$ and $\mathrm{Fe}$ than $\mathrm{C}$-slag. Compared to BF-slag, PTC slag contained higher $\mathrm{Fe}, \mathrm{Ca}, \mathrm{P}, \mathrm{Mn}$, and $\mathrm{Na}$ but lower Si, $\mathrm{Al}$, and $\mathrm{K}$.

The above results indicate that for soil amendment, PTC slag will supply much higher $P$ and slightly higher $\mathrm{Ca}$ than $\mathrm{C}$-slag and BF-slag. Therefore, the use of PTC slag as a liming material can hopefully reduce the demand of $P$ fertilizer. Nevertheless, the capacity of PTC slag to supply $\mathrm{Mg}$ was smaller than those of the two slags.

Table 2 also shows that the neutralizing value of PTC slag was lower than that of $C$ slag and BF-slag. Neutralizing value or calcium carbonate equivalent is the acid-neutralizing capacity of an agricultural liming material expressed as a weight percentage of calcium carbonate (Tisdale et al., 1985). The result suggest that the capacity of PTC-slag in neutralizing soil acidity (increasing soil pH) was lower than those of the both slags. However, the results of buffer curve analysis of Andisol from Tochigi Prefecture (Figure 1) and Red-Yellow Podzolic (Ultisol) from Mie Prefecture (Figure 2) for various particle sizes of PTC slag and C slag indicated that the ability of all particle sizes of PTC slag to neutralize the acidity of Andisol and Red-Yellow Podzolic were markedly greater than those of $\mathrm{C}$ slag.

Buffer curve method measures the ability of a liming material to neutralize the acidity of a soil, while neutralizing value only expresses the capacity of a liming material to neutralize the acidity. The ability of a liming material to neutralize the acidity of a soil is determined by soil factor (buffer capacity of soil) and liming material factor - neutralizing value and reactivity. As shown in Figures 1 and 2, the ability of both PTC slag and C slag to neutralize the acidity of Andisol were lower than those to neutralize the acidity of Red-Yellow Podzolic soil. This indicated that buffer capacity of the Andisol was higher than that of the Red-Yellow Podzolic soil.

Reactivity of a liming material is determined by the solubility of chemical compound in the liming material and its particle size (Miller and Donahue, 1995). The high ability of PTC slag to neutralize soil acidity might be attributed to its high content of $\mathrm{Na}$. Possibly $\mathrm{Na}$ element play a role in enhancing the solubility of slag.

\section{Application of PTC slag as a Liming Material and $P$ Fertilizer}

Effects of combination of various liming materials and SP on yield (fresh weight of top part of the plant) of komatsuna are presented in Figure 3 . The results of analysis of variance and HSD test indicated that liming materials and its combination with SP had significant effects on the growth of komatsuna. Without SP, PTC slag and C slag adjusting soil $\mathrm{pH}$ to 6.5 and 7.5 significantly increased the yield of komatsuna. Application of PTC-slag, however, provided better yield than that of C slag.

Andisol used in the experiment had $\mathrm{pH}\left(\mathrm{H}_{2} \mathrm{O}\right)$ value of 4.8, which was classified into strongly acid (Brady and Weil, 1996). Nevertheless, due to its low exchangeable $\mathrm{Al}\left(1.07 \mathrm{cmol}(+) \mathrm{kg}^{-1}\right)$, problem of $\mathrm{Al}$ toxicity for komatsuna plant did not arise in the experiment. Application of dolomite had no significant effect on the growth of the plant, whereas application of SP did. Moreover, the result of plant analysis indicated that the $P$ content in top part (Figures 4) as well as its $P$ uptake (Figure 5) on untreated soil were very low, and they were not improved with application of dolomite, but were improved with application of SP. These results suggested that the limiting factor for growth of komatsuna in this experiment was P supply, and its poor growth on untreated soil was associated with the deficiency of $P$.

As application of dolomite had no significant effect on plant growth, but application of PTC slag or C slag gave a significant effect on plant growth and yield. The effects were apparently attributed to their supply of P. Application of PTC slag tended to have better result than that of C-slag. Crop yield, $P$ content in, top part of the plant, and soil available $P$ were higher after application of PTC slag than those after application of $C$ slag (Table 4). These evidences indicated that PTC slag was able to supply more $P$ than $C$ slag, and it agreed well with their citric acid soluble $P$ and total content of $P$.

As shown in Figure 3, addition of SP of 2.5 and $5.0 \%$ PAC to PTC slag improved the yield of komatsuna. The effect of the SP addition, however, was better to PTC slag adjusting soil pH to 6.5 than to PTC slag adjusting soil pH to 7.5. On the other hand, the addition of SP of the same dosage to C slag or dolomite significantly improved 
the yield both to $\mathrm{C}$ slag or dolomite adjusting soil $\mathrm{pH}$ to 6.5 and 7.5. Furthermore, the yield after application of PTC slag adjusting soil pH to 7.5 was not significantly different from those after application of $\mathrm{C}$ slag (both for adjusting soil $\mathrm{pH}$ to 6.5 and 7.5 ) combined with SP of 2.5 and $5.0 \%$ PAC. Moreover, results of the experiment also indicated that the available $P$ in soil after application of PTC slag adjusting soil $\mathrm{pH}$ to $7.5\left(41.3 \mathrm{mg} \mathrm{kg}{ }^{-1}\right)$ was not different from different from that after application of C slag adjusting soil pH to 6.5 combined with SP of $5 \%$ PAC and that after application of C slag adjusting soil $\mathrm{pH}$ to 7.5 combined with $\mathrm{SP}$ of $2.5 \%$ experiment. Application of PTC slag combined with SP of 5\% PAC or application of C slag combined with SP of $5 \%$ PAC produced greater yield than application of dolomite combined with SP of $5 \%$ PAC. The $B$ content of plant and soil available $B$ were higher after application of C slag or PTC slag combined with SP of $5 \%$ PAC than that after application of dolomite combined with SP of the same dosage. These results suggested that the better effect of PTC slag or C slag combined with SP of $5 \%$ PAC as compared to dolomite combined with SP of the same dosage on crop growth and yield were attributed to their $B$ supply.

As shown Table 4, application of PTC slag and C slag significantly increased soil $\mathrm{pH}$, exchangeable $\mathrm{Ca}$ and $\mathrm{Mg}$, and available $\mathrm{B}$ and $\mathrm{Mn}$ in Andisol. Application of PTC slag both adjusting soil pH to 6.5 and 7.5 and $\mathrm{C}$ slag adjusting soil $\mathrm{pH}$ to 7.5 significantly improved the available P. PTC slag significantly increased exchangeable $\mathrm{Na}$, while $\mathrm{C}$ slag did not. Dolomite significantly increased soil

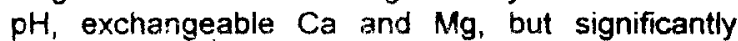
decreased available 3 . These effects were more pronounced as the amount of PTC slag, C slag, and dolomite increased. PTC slag application resulted in lower exchangeable $\mathrm{Mg}$ than $\mathrm{C}$ slag and dolomite did. Exchangeable $\mathrm{Ca}$ was, however, stightly higher after PTC slag application than after $C$ slag application. These results indicated that PTC slag had higher ability to improve available $P$ in soil, but lower ability to improve the exchangeable $\mathrm{Mg}$ than C slag.

In this experiment, although the exchangeable $\mathrm{Na}$ in the soil after PTC slag application was about 4.5 to 8.3 fold that after $C$ slag application, the $\mathrm{Na}$ uptake of komatsuna top part after PTC slag application was only 2.4 to 2.8 fold that after $C$ slag application (Figure 6)

Compared to dolomite, PTC slag supplied remarkably lower $\mathrm{Mg}$; however, this slag could also supply $P$ and $B$. Nevertheless, result of this pot experiment indicated that there was no symptom of $\mathrm{Mg}$ deficiency in komatsuna after PTC slag application. Application of dolomite, on the other hand, could not eliminate the $P$ deficiency and its application in high dosage (adjusting soil pH to 7.5) could induce the B deficiency. Therefore, for a liming material, PTC slag was better than dolomite.
PAC. These indicated that PTC slag adjusting soil $\mathrm{pH}$ to 7.5 supplied sufficient $P$ to meet the $P$ demand of komatsuna plant.

Application of dolomite adjusting soil $\mathrm{pH}$ to 7.5 combined with SP of $2.5 \%$ PAC produced the lowest komatsuna yield. . As shown in Table 3, the B content in top part of komatsuna after this treatment was very low. Apparently this low komatsuna yield be associated with B supply, and B was the second growth limiting factor in this pot

\section{CONCLUSION}

PTC slag had high EC value and citric acid soluble $P$. This slag contained more $\mathrm{Ca}, \mathrm{Si}, \mathrm{P}, \mathrm{K}$, and $\mathrm{Na}$ but less $\mathrm{Mg}$ and $\mathrm{Fe}$ than Cslag. Compared to $\mathrm{BF}$ slag, PTC slag contained more $\mathrm{Fe}, \mathrm{Ca}, \mathrm{Mg}, \mathrm{P}, \mathrm{Mn}$, and $\mathrm{Na}$ but less $\mathrm{Si}, \mathrm{Al}$, and $\mathrm{K}$. Although neutralizing value of PTC slag was quite low, its ability to neutralize soil acidity was high. For acid soil amendment, PTC slag was better than dolomite because of its ability to supply $P$ and $B$. This slag was superior in supplying $P$ than $C$ slag. Application of PTC slag for acid soil amendment could reduce the demand of $P$ fertilizer, and the $P$ supply from high dosage could fulfill the $P$ requirement of komatsuna plant.

Acknowledgments: The authors thank Kawasaki Steel Mizushima Works for supplying PTC slag material. Thanks also due to Mr. Makoto Hosoya, Miss. Naoko Takayama, and Miss. Asuka Takeo for their help in the pot experiment.

\section{REFERENCES}

Anonymous. 1994. Profile in Steel. Mizushima Works, Kawasakı Steel Corporation, Kurashiki.

Anonymous. 1996. Properties and Effective Uses of Steel Slag. Nippon Slag Association, Tokyo.

Brady, N. C. and R. R. Weal. 1996. The Nature and Properties of Soils. $11^{\text {th }}$ ed. Prentice Hall, Inc., New Jersey.

Carter, O. R., B. L.Collier, and F. L. Davis. 1951. Blast fumace slag as agricultural liming materials. Agron. J., 43:430-433.

Crane, F. H. 1930. A comparison of some effects - of blast furnace slag and limestone on an acid soil. J. Am. Soc. Agron., 22:968 -973.

Goto, I. 1987. Studies on the effects of iron and steel slags on soil improvement. Doctorate Thesis, Tokyo University of Agriculture. (Unpublished). 
Miller, R. W. and R. L. Donahue. 1995. Soils in Our Environment $t$. $7^{\text {th }}$ ed. Prentice-Hall, Inc. Englewood Cliffs, New Jersey.

Naftel, J. A. 1937. Soil liming investigation V: The relation of boron deficiency to over-liming injury. J. Am. Soc. Agron., 29:761 -771.

Nishiwaki, M. 1986. Tekko. (3) Seiko (gangokintetsu). 184-192. In sekkaiseki no yoto to tokusei. Sekkaiseki Kogyo Kyokai, Tokyo. (In Japanese).

Steel, R. G. D. and J. H. Torrie. 1980. Principles and Procedures of Statistics. $2^{\text {nd }} \mathrm{ed}$. McGraw-Hill, Inc., New York.

Suwarno and I. Goto. 1997. Mineralogical and chemical properties of Indonesian electric furnace slag and its application effect as soil amendment. $\downarrow$ Agric. Sci. Tokyo Nogyo Daigaku (Tokyo Univ. Agric.), 42:151-162.

Tisdale, S. L., W. L. Nelson, and J. D. Beaton. 1985. Soil Fertility and Fertilizers. $4^{\text {th }} \mathrm{ed}$. Macmillan Publishing Company, New York.

Umegaki, K. 1986. Tekko. (1) Gaisetsu. 175-179. In sekkaiseki no yoto to tokusei. Sekkaiseki Kogyo Kyokai, Tokyo. (In Japanese).

Washimi, K. 1986. Tekko. (5) Suragu. 200-205. In sekkaiseki no yoto to tokusei. Sekkaiseki Kogyo Kyokai, Tokyo. (In Japanese).

Wild, A. 1988. Plant nutrient in soil: phosphate. 695-742. In A. Wild (ed.) Russell's soil condition and plant growth. $11^{\text {th }}$ ed. Longman Scientific \& Technical, England. 
Table 1. Chemical Properties of Pretreatment Center, Converter, and Blast Furnace Slags

\begin{tabular}{|c|c|c|c|c|c|c|c|c|c|c|}
\hline \multirow{3}{*}{ Kind of Slag } & \multirow{3}{*}{$\begin{array}{c}\text { Particle } \\
\text { Size } \\
(\mathrm{mm})\end{array}$} & \multicolumn{4}{|c|}{ Distribution of Particle Size } & \multirow{2}{*}{$\begin{array}{l}\mathrm{pH} \\
\left(\mathrm{H}_{2} \mathrm{O}\right)\end{array}$} & \multirow[t]{2}{*}{ EC } & \multicolumn{3}{|c|}{ Citric Acid Soluble } \\
\hline & & $<0.25$ & $0.25-0.50$ & $0.50-1.0$ & $1.0-2.0$ & & & \multirow{2}{*}{$\begin{array}{c}\mathrm{P}_{2} \mathrm{O}_{5} \\
\cdots\left(\mathrm{g} \mathrm{kg}^{-1}\right.\end{array}$} & $\mathrm{SiO}_{2}$ & \multirow{2}{*}{$\begin{array}{r}8 \\
1 \\
\end{array}$} \\
\hline & & ......... & ( & -................... & $\cdots$ & $1: 5$ & $\left(\mathrm{dS} \mathrm{m}^{-1}\right)$ & & & \\
\hline PTC slag & $<2.0$ & 40.9 & 26.5 & 18.1 & 14.3 & 12.6 & 10.73 & 21.6 & 113.7 & 102.2 \\
\hline C Slag & $<2.0^{\circ}$ & 37.3 & 18.3 & 21.1 & 23.1 & 12.7 & 8.47 & 8.9 & 59.6 & 91.9 \\
\hline BF Slag & $<2.0$ & 3.4 & 24.0 & 53.3 & 18.7 & 9.9 & 0.16 & 0.3 & 199.9 & 45.7 \\
\hline
\end{tabular}

Table 2. Chemical Composition of Pretreatment Center, Converter, and Blast Furnace Slags

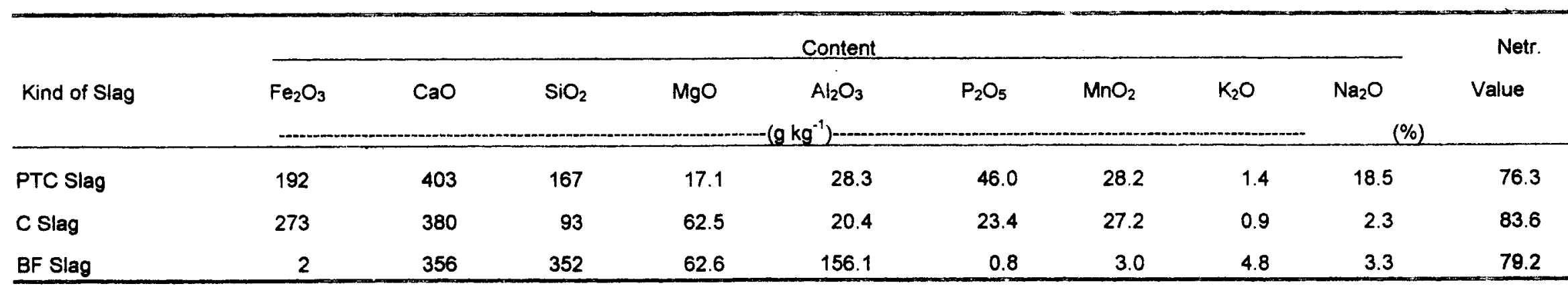

Table 4. Effects of Various Liming Materiais and Super Phosphate of $0 \%$ PAC on Chemical Properties of Andisol

\begin{tabular}{|c|c|c|c|c|c|c|c|c|}
\hline \multirow[b]{2}{*}{ No. Treatment } & \multirow{2}{*}{$\begin{array}{l}\mathrm{pH} \\
\mathrm{H}_{2} \mathrm{O} \\
1: 5\end{array}$} & \multicolumn{4}{|c|}{ Exchangeable Bases } & \multicolumn{3}{|c|}{ Available } \\
\hline & & $\mathrm{Ca}$ & $\mathrm{Mg}$ & $k$ & $\mathrm{Na}$ & $\overrightarrow{\mathrm{P}_{2} \mathrm{O}_{5}}$ & $\begin{array}{c}\mathrm{Mn} \\
\left.\mathrm{kg}^{-1}\right)\end{array}$ & $\bar{B}$ \\
\hline $\begin{array}{l}1 \text { Unlimed } \\
2 \text { Dol. pH } 6.5 \\
3 \text { PTC Slag pH } 6.5 \\
4 \text { C Slag pH } 6.5 \\
5 \text { Dol. pH } 7.5 \\
6 \text { PTC Slag pH } 7.5 \\
7 \text { C Slag pH } 7.5 \\
\end{array}$ & $\begin{array}{l}4.9 \\
6.7 \\
6.0 \\
6.0 \\
7.2 \\
7.0 \\
7.0 \\
\end{array}$ & $\begin{array}{r}0.9 \\
27.5 \\
27.1 \\
25.3 \\
42.1 \\
60.3 \\
56.7 \\
\end{array}$ & $\begin{array}{r}0.33 \\
18.11 \\
1.03 \\
3.15 \\
21.00 \\
2.00 \\
5.00 \\
\end{array}$ & $\begin{array}{l}1.02 \\
0.94 \\
0.69 \\
0.80 \\
0.65 \\
0.38 \\
0.51 \\
\end{array}$ & $\begin{array}{l}0.37 \\
0.41 \\
2.18 \\
0.45 \\
0.23 \\
4.29 \\
0.59 \\
\end{array}$ & \begin{tabular}{rl|}
0.1 \\
5.4 \\
13.7 \\
6.8 \\
3.8 \\
41.3 \\
18.0 \\
\end{tabular} & $\begin{aligned} 0.6 \\
3.4 \\
31.3 \\
12.9 \\
3.7 \\
143.2 \\
89.8 \\
\end{aligned}$ & $\begin{array}{l}0.15 \\
0.03 \\
0.37 \\
0.22 \\
0.02 \\
0.42 \\
0.28 \\
\end{array}$ \\
\hline $\begin{array}{l}\text { Tukey's HSD } 0.05 \\
\text { Tukey's HSD } 0.01 \\
\text { CV (\%) }\end{array}$ & $\begin{array}{l}0.19 \\
0.21 \\
0.9\end{array}$ & $\begin{array}{l}5.0 \\
5.8 \\
4.3\end{array}$ & $\begin{array}{l}1.28 \\
1.48 \\
5.97\end{array}$ & $\begin{array}{r}0.22 \\
0.25 \\
18.4\end{array}$ & $\begin{array}{c}0.89 \\
1.03 \\
23.3\end{array}$ & $\begin{array}{l}10.6 \\
12.3 \\
10.7\end{array}$ & $\begin{array}{l}14.0 \\
16.1 \\
10.3\end{array}$ & $\begin{array}{l}0.05 \\
0.06 \\
7.02\end{array}$ \\
\hline
\end{tabular}


Table 3. Effects of Various Liming Materials and Super Phosphate of $2.5 \%$ PAC on Nutrient Content in Komatsuna Top Part

\begin{tabular}{|c|c|c|c|c|c|}
\hline \multirow{3}{*}{ No. Treatment } & \multicolumn{5}{|c|}{ Content } \\
\hline & $\mathrm{Ca}$ & $\mathrm{Mg}$ & $\mathrm{Na}$ & $\mathrm{Mn}$ & $B$ \\
\hline & \multicolumn{3}{|c|}{$\left(g^{~ k g}{ }^{-1}\right)$} & \multicolumn{2}{|c|}{$\ldots(m g ~ k g-1)-\cdots$} \\
\hline 1 Unlimed & 15.4 & 1.5 & 5.7 & 170 & 25.3 \\
\hline 2 Dol. pH 6.5 & 27.7 & 14.4 & 3.4 & 118 & 16.0 \\
\hline 3 PTC Slag pH 6.5 & 23.2 & 2.1 & 6.6 & 253 & 48.7 \\
\hline $4 \mathrm{C}$ Slag pH 6.5 & 37.3 & 5.8 & 3.8 & 268 & 40.8 \\
\hline 5 Dol. $\mathrm{pH} 7.5$ & 32.1 & 11.4 & 4.3 & 125 & 12.1 \\
\hline 6 PTC Slag pH 7.5 & 20.3 & 2.1 & 7.5 & 283 & 41.9 \\
\hline 7 C Slag $\mathrm{pH} 7.5$ & 37.6 & 5.7 & 3.3 & 400 & 41.7 \\
\hline
\end{tabular}

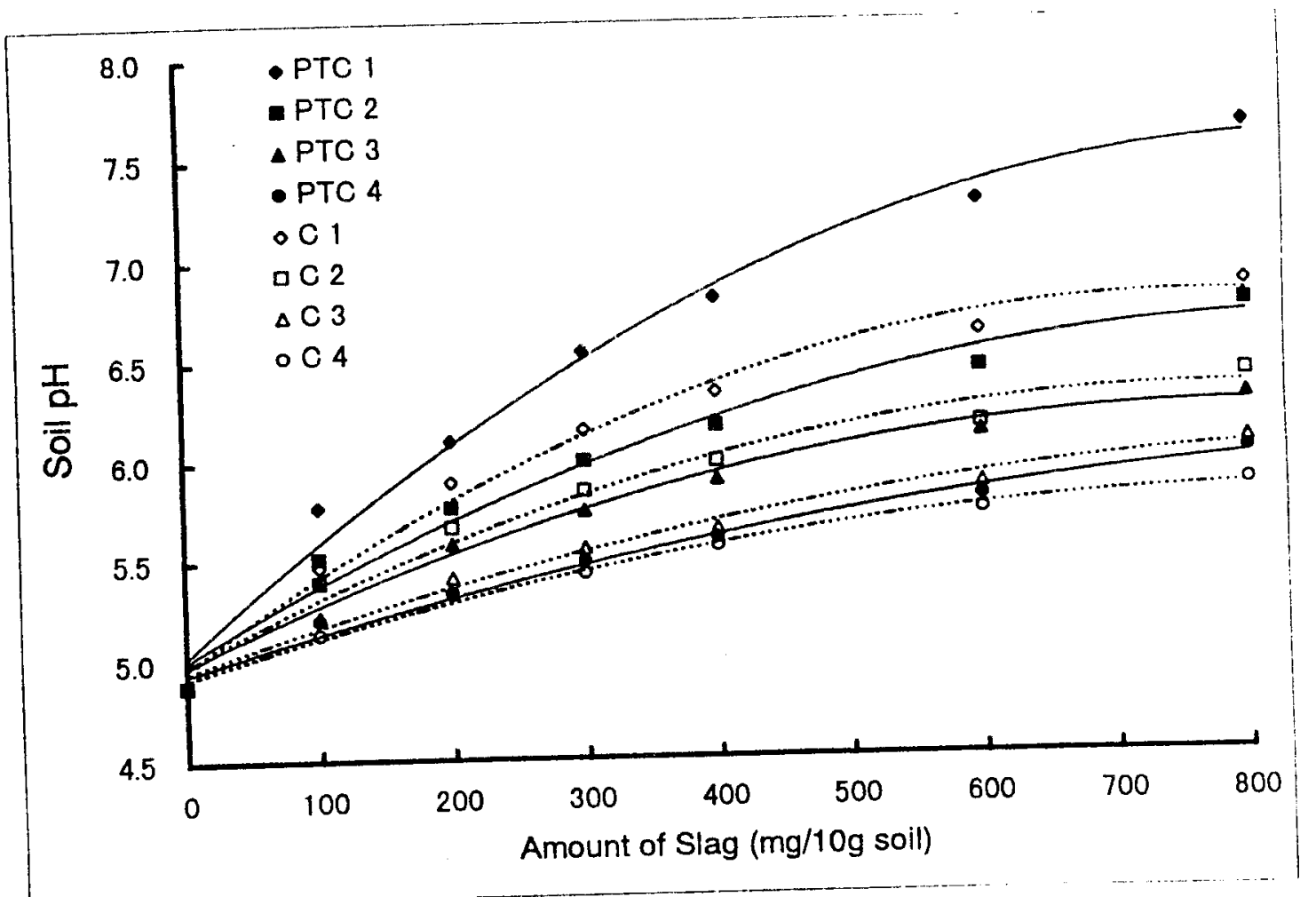

Figure 1. Buffer curve of Andisol from Tochigi prefecture for PTC and C slags 


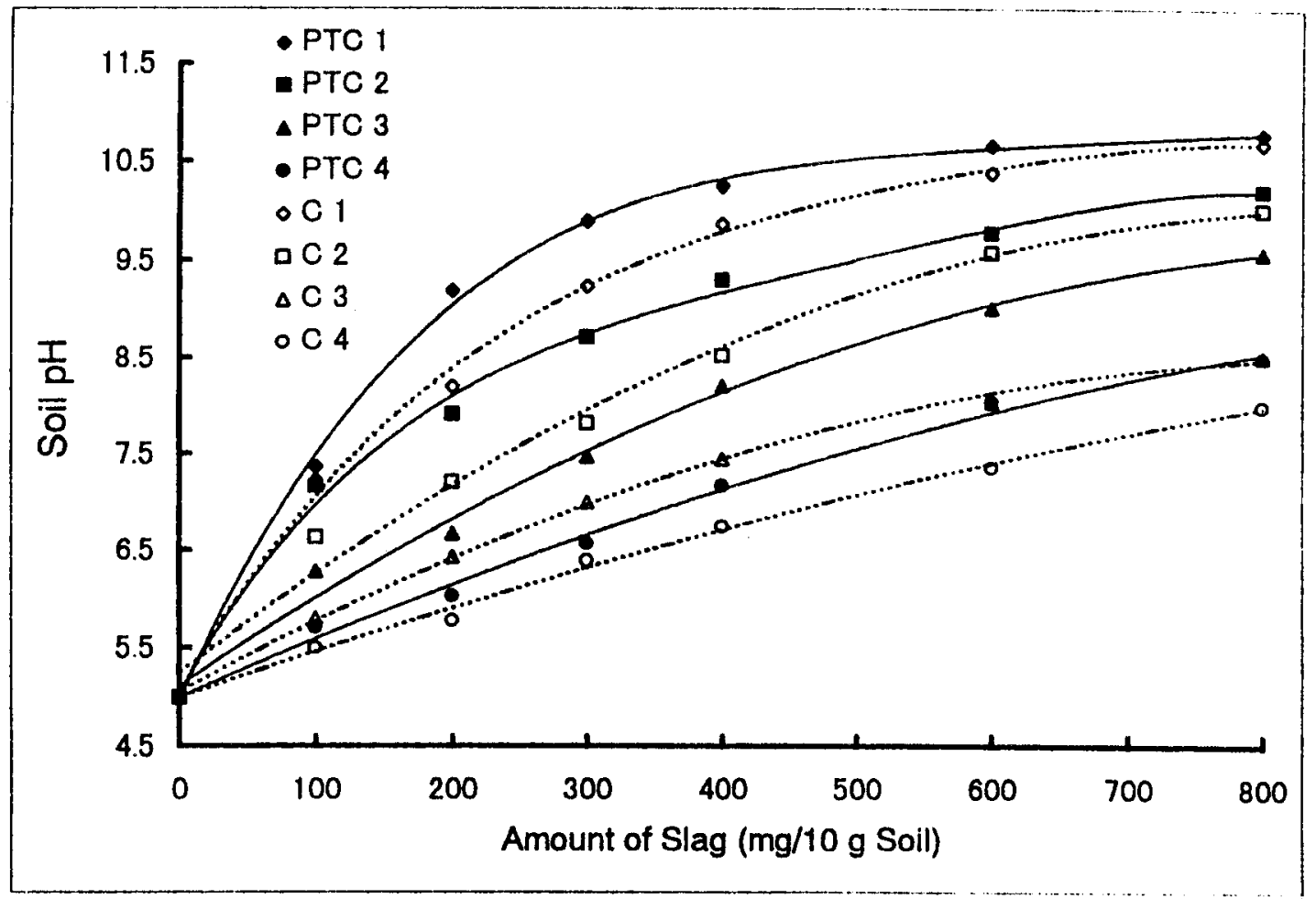

Figure 2. Buffer curve of Red-Yellow Podzolic soil from Mie prefecture for PTC and C slags

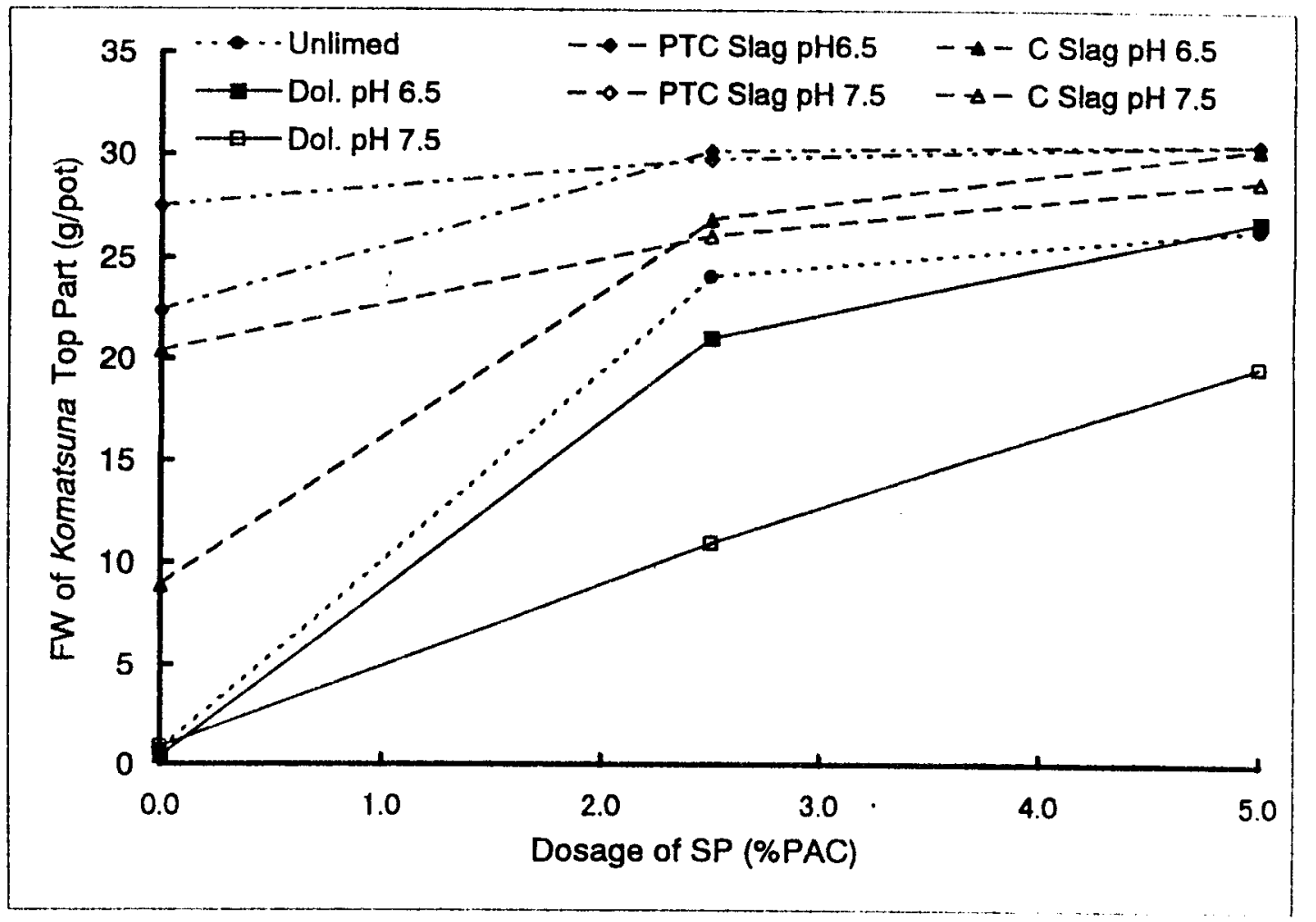

Figure 3. Effects of combination of various liming materials and super phosphate on yield of komatsuna 


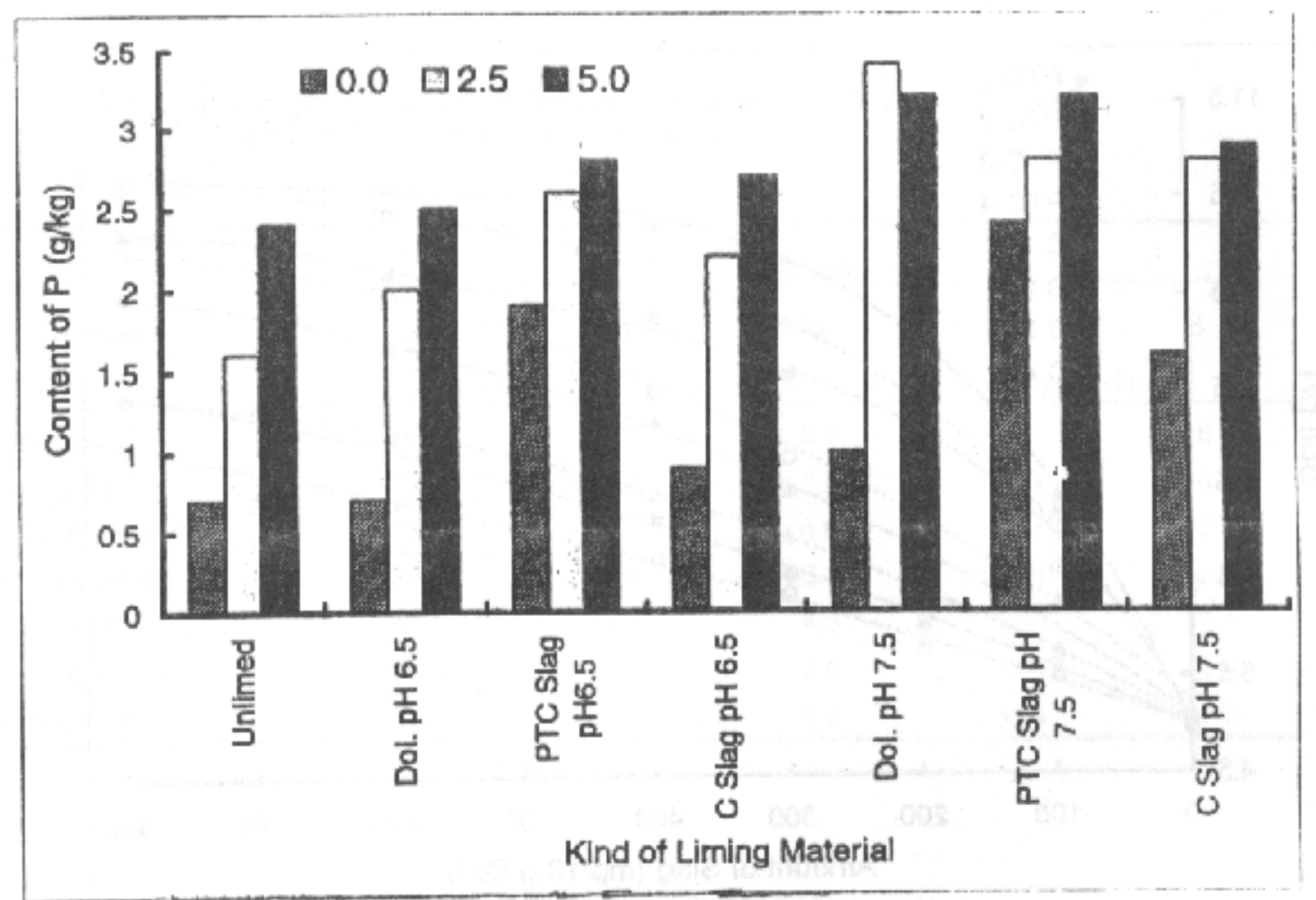

Figure 4. Effects of combination of various liming materials and super phosphate on $P$ content of komatsuna top part

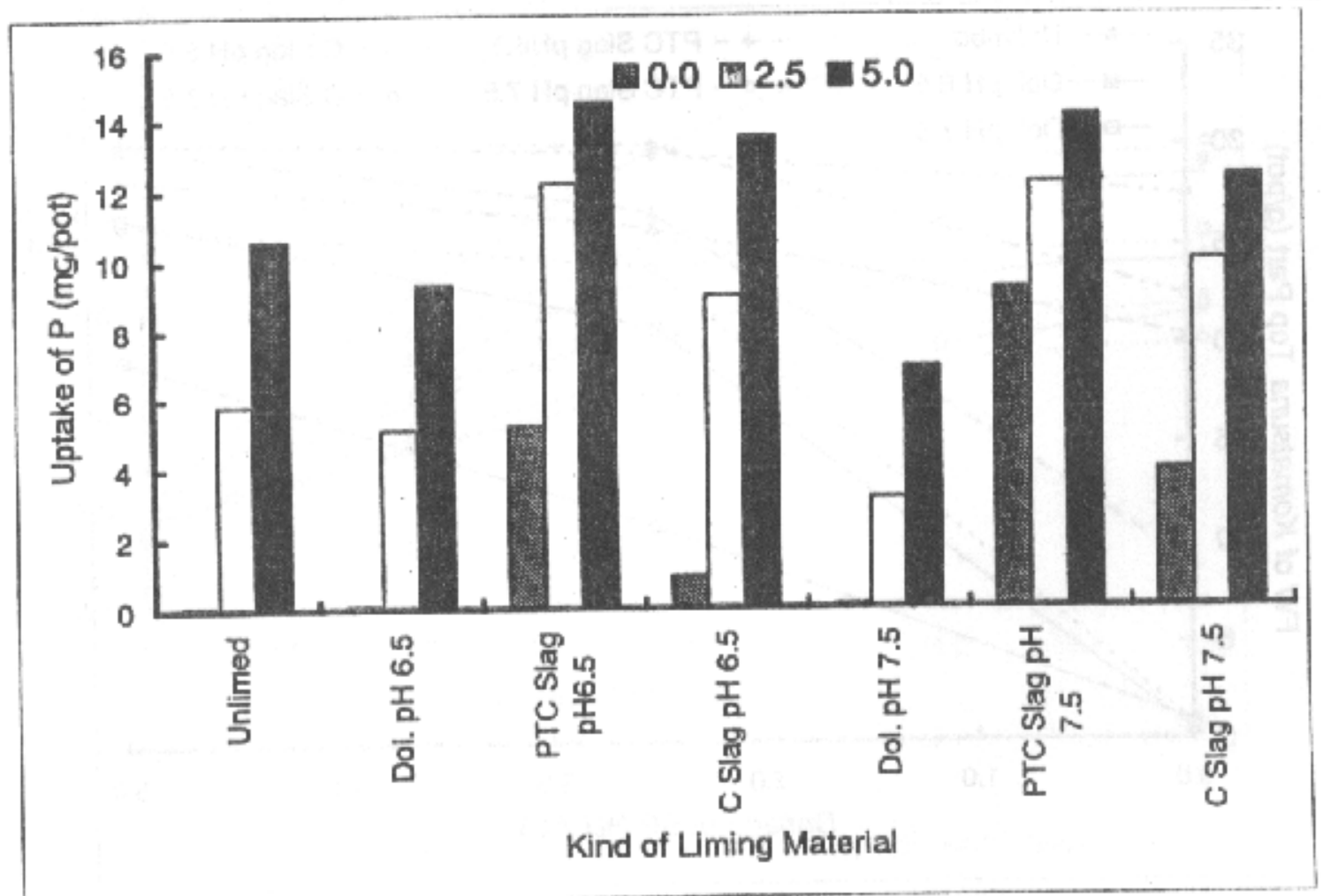

Figure 5. Effects of combination of various liming materials and super phosphate on $P$ uptake of komatsung top part 


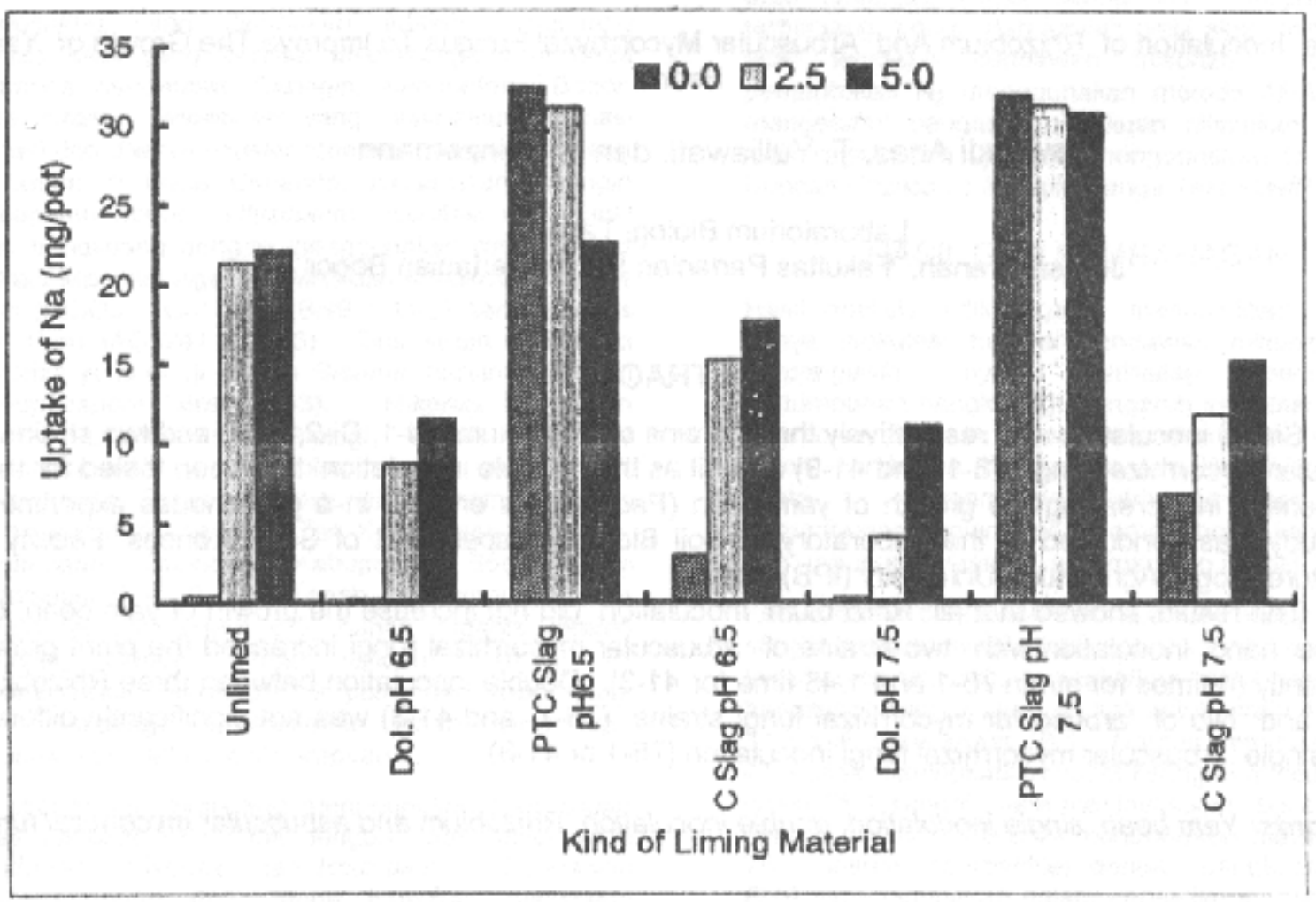

Figure 6. Effects of combination of various liming materials and super phosphate on Na uptake of komatsuna top part 